\title{
MOLECULAR PHYLOGENY OF VENERIDAE (MOLLUSCA:BIVALVIA) BASED ON NUCLEAR RI- BOSOMAL INTERNAL TRANSCRIBED SPACER REGION
}

\author{
AMPILI M. ${ }^{* *}$ AND SREEDHAR S.K. ${ }^{2}$ \\ 1Department of Zoology, N.S.S. Hindu College, Changanassery- 686 102, Kerala, India. \\ 2Department of Zoology, S.N. College, Cherthala- 688 530, Kerala, India. \\ *Corresponding Author: Email- ampilirajeev@gmail.com
}

Received: April 03, 2014; Accepted: April 24, 2014

\begin{abstract}
In the present study, molecular phylogeny of bivalve family Veneridae (Mollusca:Bivalvia) was analysed using internal transcribed spacer (ITS) region of 21 species belonging to different subfamilies of Veneridae. ITS of ribosomal DNA can be utilised for delineating evolutionary and genetic relationships between closely related taxa. ITS region of Paphia malabarica belonging to subfamily Tapetinae and Meretrix casta belonging to meretricinae was sequenced. Total genomic DNA was extracted from the adductor muscle using CTAB protocol and the internal transcribed spacer region of nuclear ribosomal DNA was PCR amplified and sequenced using ITS (ITS1 and ITS2) forward and reverse primers. Total length of sequence was found to be $895 \mathrm{bp}$ in Paphia malabarica and $785 \mathrm{bp}$ in Meretrix casta. GC contents in the sequences were found to be $58.99 \%$ and $64.68 \%$ respectively in Paphia malabarica and Meretrix casta. ITS1 region of Paphia malabarica consisted of 393 bp with GC content $58.12 \%$ and 309 bp with $63.75 \%$ GC content in Meretrix casta. ITS2 region generated 248bp with $63 \%$ GC content in Paphia malabarica and 240bp with $72.06 \%$ GC content in Meretrix casta. $5.8 \mathrm{~S}$ region rendered $157 \mathrm{bp}$ with $60 \% \mathrm{GC}$ content in Paphia malabarica and 138bp with $61.32 \%$ GC content in Meretrix casta. Phylogenetic trees were constructed using Neighbor-Joining and Maximum-Parsimony methods. The analysis produced trees with similar topology. The tree topologies indicated two clades with three well resolved groups. Phylogenetic analysis supported the morphological classification and monophyly of the family Veneridae.
\end{abstract}

Keywords- Veneridae, internal transcribed spacers, phylogenetic trees, clades, monophyly

Citation: Ampili M. and Sreedhar S.K. (2014) Molecular Phylogeny of Veneridae (Mollusca:Bivalvia) based on Nuclear Ribosomal Internal Transcribed Spacer Region. International Journal of Molecular Biology, ISSN: 0976-0482 \& E-ISSN: 0976-0490, Volume 5, Issue 1, pp.- 096101.

Copyright: Copyright@2014 Ampili M. and Sreedhar S.K. This is an open-access article distributed under the terms of the Creative Commons Attribution License, which permits unrestricted use, distribution and reproduction in any medium, provided the original author and source are credited.

\section{Introduction}

The family Veneridae is a cosmopolitan and ubiquitous bivalve family, commonly known as "Venus clams". There are about 800 extant species currently ordered in to 12 subfamilies according to a morphology - based classification [1]. Most of the Venerid clams are ecologically important and commercially valuable. Veneridae contribute a significant proportion of world's edible bivalve fishery. The members of the family exhibit morphological parallelism among evolutionary distant species and shell diversification among closely related species. This complicates the study of phylogenetic relationship among Venerid clams. Hence, new approaches and methods employing molecular markers were utilised for phylogenetic study of Veneridae.

The taxonomy of Veneridae was elucidated using various methodological approaches such as karyological analysis [2], radioimmunoassay [3], enzyme electrophoresis [4], highly repetitive DNA [5], biochemical approaches and methods based on sperm morphology [6]. Venerid phylogeny was studied using the mitochondrial 16S rRNA gene $[7,8]$. Several researchers employed ITS region or one of its spacers in different bivalve families to delineate the phylogenetic relationships of many bivalve species [9-17].
The nuclear ribosomal DNA is a cluster of repeat units consisting of 18S, ITS1, 5.8S, ITS2 and 28S genes. In most eukaryotes the ITSS exist in several hundred copies in one or several loci and in one or several chromosomes. ITS1 and ITS2 are non coding regions located in rDNA $[18,19]$. Within a genome the nuclear rDNA copies are highly homogenous due to concerted evolution.

In the present study we made an attempt to sequence the nuclear ribosomal internal transcribed spacers in two Venerid clams Paphia malabarica and Meretrix casta and to study the phylogeny of Veneridae using the sequences generated and 19 sequences published earlier.

\section{Materials and Methods}

\section{Sample Collection and DNA Extraction}

Live adult clam samples of Paphia malabarica and Meretrix casta were collected from the clam beds of Ashtamudi Lake (Kerala, India). Twenty specimens of each species were used for the DNA extraction and the study was completed in two years. Total genomic DNA was extracted from $200 \mathrm{mg}$ of adductor muscle using modified CTAB protocol [20]. 


\section{PCR Amplification and Sequencing}

The internal transcribed spacer region of nuclear ribosomal DNA was amplified using the following primers. ITS1 $\mathrm{F}\left(5^{\prime}\right.$-GGTGAACCT GCGGATGGA-3') and ITS1R (5'-GCTGGCTGCGCTCTTCAT-3') are primers that annealed to the 3'end of 18S rRNA gene and the 5.8S rRNA gene, respectively. ITS2 region was amplified using ITS2 F (5'-ATGAAGAGCGCAGCCAGC-3') and ITS2R (5'-GGCTC TTCCCGCTTCACTC-3') as primers that annealed to the $5.8 S$ rRNA gene and the $5^{\prime}$ end of $28 \mathrm{~S}$ rRNA gene. PCR were performed in a total reaction mixture of $50 \mu \mathrm{l}$ of the isolated genomic DNA from clam samples to amplify the ITS region. The PCR were performed with the above mentioned primer pair. The PCR mixture contained $1 \mu$ of isolated genomic DNA (50ng) from each sample, $1 \mu$ l of each primer (10 pmol/ $\mu \mathrm{l}), 2 \mu \mathrm{l} 10 \mathrm{mM}$ deoxyribonucleoside triphoshate, 5 $\mu \mathrm{l} 10 \mathrm{X}$ PCR buffer containing $\mathrm{MgCl}_{2}$, and $1 \mu$ I of $5 \mathrm{U} / \mu \mathrm{l}$ Taq DNA Polymerase. The PCR reaction was conducted with the initial denaturation at $94^{\circ} \mathrm{C}$ for 2 minutes followed by denaturation at $94^{\circ} \mathrm{C}$ for 45 seconds, annealing at $62^{\circ} \mathrm{C}$ for 60 seconds and elongation at $72^{\circ} \mathrm{C}$ for $2 \mathrm{~min}$. These cycles were then followed by 34 cycles of denaturation, Annealing and elongation followed by an extended final elongation step at $72^{\circ} \mathrm{C}$ for $10 \mathrm{~min}$. The PCR products were electrophoresed in a $1 \%(\mathrm{w} / \mathrm{v})$ agarose gel stained with ethidium bromide and observed on an UV transilluminator. The amplicon was excised from the gel and the DNA was eluted from the gel slice by using GeneJet Gel extraction kit (Fermentas) according to the manufacturer's specifications. Sequencing was done using the big dye terminator kit in ABI $3730 \mathrm{XL}$ DNA analyzer. The obtained forward and reverse sequences were aligned to get the contig using Sequencher software and were analysed.

\section{Sequence Alignment and Phylogenetic Analysis}

The sequences obtained were identified using NCBI-BLAST [21]. The species name and the accession numbers of the sequences are given in [Table-1]. All sequences were aligned using multiple sequence alignment option of CLUSTALW (EMBL-EBI) and rechecked using CLUSTALX [22].

The phylogenetic trees were constructed using SeaView version 4 [23] and MEGA version 5[24] in two different phylogenetic modes of Neighbor-Joining (NJ) and Maximum-Parsimony (MP). Kimura's 2parameter distance model was employed to construct NeighborJoining trees. Maximum- Parsimony tree was obtained using the

Close-Neighbor-Interchange algorithm [25]. Complete deletion options were used for handling gaps in all analyses. The bootstrap values [26], indicate the robustness of nodes in Neighbor-Joining and Maximum- Parsimony trees, inferred from 500 replications.

\section{Results}

\section{PCR Amplification and Data Analysis}

The entire ITS region was amplified from 10 individuals of the two clam species. In all cases PCR yielded a single band of approximately 900 base pairs in length for Paphia malabarica and 800 base pairs in length for Meretrix casta. The sequences were registered in the GenBank and the accession numbers were given in [Table-1]. Using the sequence information of Arctica islandica (GenBank accession number AF202106), the boundaries of coding and spacer regions were determined. [Table-2] depicts the species name, total length, AT content and GC content of the PCR products and their ITS1, 5.8S rDNA, ITS2, and 28S rDNA of the two species.

Table 1- Species used for the phylogenetic analysis and their GenBank accession numbers

\begin{tabular}{lc}
\hline Species & Accession Number \\
\hline Arctica islandica haplotype TJ1 & AF202106 \\
Paphia malabarica & JX997826 \\
Protothaca staminea & EF035084 \\
Protothaca jedoensis haplotype JL2 & $\mathrm{DQ} 220291$ \\
Protothaca jedoensis haplotype JL1 & $\mathrm{DQ} 220290$ \\
Venerupis (Ruditapes) philippinarum & $\mathrm{EF} 035088$ \\
Venerupis (Ruditapes) philippinarum strain CX & $\mathrm{AY} 498758$ \\
Venerupis (Ruditapes) philippinarum strain ZH & $\mathrm{AY} 498757$ \\
Cyclina sinensis & $\mathrm{DQ} 273168$ \\
Chamelia gallina & $\mathrm{HE} 965774$ \\
Paphia amabilis isolate TaPam1 & $\mathrm{JN} 996783$ \\
Mercenaria mercenaria haplotype Y1 & $\mathrm{DQ} 190445$ \\
Meretrix casta & $\mathrm{KC} 416613$ \\
Meretrix cf. petechialis Mpe & $\mathrm{HE} 965778$ \\
Meretrix lyrata isolate MeMly & $\mathrm{JN} 996771$ \\
Cyclina sinensis haplotype QD1 & $\mathrm{DQ} 190446$ \\
Meretrix meretrix voucher H.L.Cheng & $\mathrm{DQ} 191390$ \\
Meretrix meretrix haplotype WZ1 & $\mathrm{DQ} 399410$ \\
Venerupis (Ruditapes) philippinarum & $\mathrm{EF035085}$ \\
Saxidomus purpuratus isolate CaSpu3 & $\mathrm{JN} 996763$ \\
Venus verrucosa & $\mathrm{HE} 965801$ \\
\hline
\end{tabular}

Table 2- Species name, total length, GC content, AT content of PCR product, their ITS1, 5.8S rDNA, ITS2 and 28S rDNA

\begin{tabular}{|c|c|c|c|c|c|c|c|c|c|c|c|c|c|c|c|c|}
\hline \multirow[b]{2}{*}{ Species } & \multirow{2}{*}{$\begin{array}{c}\text { GenBank } \\
\text { Accession } \\
\text { Number }\end{array}$} & \multicolumn{3}{|c|}{ Total } & \multicolumn{3}{|c|}{ ITS1 } & \multicolumn{3}{|c|}{ 5.8SrDNA } & \multicolumn{3}{|c|}{ ITS2 } & \multicolumn{3}{|c|}{ 28SrDNA } \\
\hline & & $\begin{array}{l}\text { Length } \\
\text { (bp) }\end{array}$ & $\begin{array}{l}\text { AT } \\
(\%)\end{array}$ & $\begin{array}{l}\mathrm{GC} \\
(\%)\end{array}$ & $\begin{array}{l}\text { Length } \\
\text { (bp) }\end{array}$ & $\begin{array}{l}\text { AT } \\
(\%)\end{array}$ & $\begin{array}{l}\mathrm{GC} \\
(\%)\end{array}$ & $\begin{array}{l}\text { Length } \\
\text { (bp) }\end{array}$ & $\begin{array}{l}\text { AT } \\
(\%)\end{array}$ & $\begin{array}{l}\mathrm{GC} \\
(\%)\end{array}$ & $\begin{array}{l}\text { Length } \\
\text { (bp) }\end{array}$ & $\begin{array}{l}\text { AT } \\
(\%)\end{array}$ & $\begin{array}{l}\text { GC } \\
(\%)\end{array}$ & $\begin{array}{c}\text { Length } \\
\text { (bp) }\end{array}$ & $\begin{array}{l}\text { AT } \\
(\%)\end{array}$ & $\begin{array}{l}\text { GC } \\
(\%)\end{array}$ \\
\hline Paphia malabarica & JX997826 & 895 & 41 & 58.99 & 393 & 41.88 & 58.12 & 157 & 40 & 60 & 248 & 37 & 63 & 97 & 48.45 & 51.55 \\
\hline Meretrix casta & KC416613 & 787 & 35.32 & 64.68 & 309 & 36.25 & 63.75 & 138 & 38.68 & 61.32 & 240 & 27.94 & 72.06 & 100 & 49 & 51 \\
\hline
\end{tabular}

The total length of the sequence was found to be 895 base pairs in Paphia malabarica and 787 base pairs in Meretrix casta. The sequence of Paphia malabarica showed $58.99 \%$ GC content and that of Meretrix casta exhibited $64.68 \%$. The ITS1 sequence consisted of 393 base pairs in Paphia malabarica and 309 base pairs in Meretrix casta. $63.75 \%$ GC content was recorded in Meretrix casta and $58.12 \%$ in Paphia malabarica. No microsatellites were found in the ITS1 region of Paphia malabarica where as the ITS1 region of Meretrix casta exhibited 3 dinucleotide microsatellites [Table-3].
Table 3- Microsatellites in the ITS1 region

\begin{tabular}{lccc|} 
Species & GenBank accession No & Microsatellites & Location \\
\hline Paphia malabarica & JX997826 & - & - \\
\hline \multirow{3}{*}{ Meretrix casta } & & CGCGCG & $38-43$ \\
& \multirow{2}{*}{ KC416613 } & GAGAGA & $247-252$ \\
& & CGCGCG & $275-280$ \\
\hline
\end{tabular}

Two microsatellites (CG) with 3 repeat units from 38 to 43 base pairs and from 275 to 280 base pairs and one microsatellite (GA) 
with 3 repeat units from 247 to 252 base pairs were observed in ITS1 region of Meretrix casta. Two conserved motifs were found in the ITS1 region [Table-4] \& [Table-5]. The first conserved motif contained 28 base pairs and it displayed 11 polymorphic sites, two of that were transitions and the remaining 9 were transversions. The second motif was constituted by 25 base pairs and it demonstrated 4 polymorphic sites and 3 of which were transitions and one was transversion.

Table 4- First conserved motif in ITS1 region of the sequences

\begin{tabular}{lcc} 
Species & $\begin{array}{c}\text { Location in } \\
\text { ITS1 }\end{array}$ & Sequences \\
\hline Paphia malabarica & $45-72$ & CGGCGGCGAC CGGCCGTCCA CAGAGGCG \\
Meretrix casta & $28-55$ & CGGCGGCGAT CGCGCGGCGC GAACGTGG \\
\hline
\end{tabular}

Polymorphic sites seen in the first conserved motif in ITS1 region of the sequences are shown in RED

Table 5- Second conserved motif in ITS1 region of the sequences

\begin{tabular}{|c|c|c|}
\hline Species & $\begin{array}{l}\text { Location in } \\
\text { ITS1 }\end{array}$ & Sequences \\
\hline Paphia malabarica & $344-368$ & CCGCCTGTGT TGCGCGGGCG GCAGA \\
\hline Meretrix casta & $265-289$ & CCGCCCGTGT CGCGCGGGCG GTCGA \\
\hline
\end{tabular}

Polymorphic sites seen in the first conserved motif in ITS1 region of the sequences are shown in RED

The 5.8S rDNA region gave 157 base pairs in Paphia malabarica and 138 base pairs in Meretrix casta. The GC content was found to be $60 \%$ in Paphia malabarica and $61.32 \%$ in Meretrix casta. The $5.8 S$ region of Meretrix casta showed 19 deletions, 4 transitions and 7 transversion.

The ITS2 region produced was 248 base pairs long in Paphia malabarica and 240 base pairs in Meretrix casta. In the ITS2 region of Meretrix casta $72.06 \%$ GC content was recorded and in Paphia malabarica the GC content was only $63 \%$. In the ITS2 sequence of both the species dinucleotide microsatellites were recorded [Table6]. There were three dinucleotide microsatellites in the ITS2 region of Paphia malabarica. The first microsatellite was formed of three repeat units (CG) and it was located from 564 to 569 base pairs. The second microsatellites formed of four repeat units (CT) were located from 606 to 613 base pairs. The third microsatellite formed of three repeat units (GC) was located from 695 to 700 base pairs. But in Meretrix casta there was only two dinucleotide microsatellites in the ITS2 region each with 3 repeat units. The first microsatellite (CG) was located from 460 to 465 and second (GA) from 650 to 655. Two conserved motifs were detected in the ITS2 region [Table7] and [Table-8]. The first conserved motif was formed of 20 base pairs and it displayed a transversion polymorphic site. The second conserved motif with a size of 21 base pairs and it displayed a transversion polymorphic site.

\begin{tabular}{lccc|}
\hline \multicolumn{3}{c}{ Table } & 6- Microsatellites in the ITS2 region \\
Species & GenBank accession No & Microsatellites & Location \\
\hline \multirow{4}{*}{ Paphia malabarica } & \multirow{3}{*}{ JX997826 } & CGCGCG & $564-569$ \\
& & CTCTCTCT & $606-613$ \\
& \multirow{2}{*}{ Meretrix casta } & GCGCGC & $704-709$ \\
& \multirow{2}{*}{ KC416613 } & CGCGCG & $460-465$ \\
& & GAGAGA & $650-655$ \\
\hline
\end{tabular}

97 base pairs and 100 base pairs were obtained respectively from Paphia malabarica and Meretrix casta in $28 \mathrm{~S}$ rDNA region. The region showed 51.55\% GC content in Paphia malabarica and 51\% GC content in Meretrix casta.

Table 7- First conserved motif in ITS2 region of the sequences

\begin{tabular}{lcc} 
Species & Location in ITS2 & Sequences \\
\hline Paphia malabarica & $552-571$ & GCGTTGGCGA GTCGCGCGGG \\
Meretrix casta & $448-467$ & GCGTTGGCGC GTCGCGCGGG \\
\hline
\end{tabular}

Polymorphic sites seen in the first conserved motif in ITS1 region of the sequences are shown in RED

Table 8- Second conserved motif in ITS2 region of the sequences

\begin{tabular}{lcc|}
\hline Species & Location in ITS2 & Sequences \\
\hline Paphia malabarica & $578-598$ & CCCGCTCGTC CGCCGAAGAA T \\
Meretrix casta & $481-501$ & CCCGCTCGTC CGCCGAAGAC T \\
\hline
\end{tabular}

Polymorphic sites seen in the first conserved motif in ITS1 region of the sequences are shown in RED

\section{Phylogenetic Analysis}

Using the sequence generated by the present study and the 19 sequences retrieved from GenBank, the phylogenetic tree of Veneridae was constructed using Arctica islandica (GenBank accession No.202106) as an out group species with Neighbor-Joining [Fig-1] and Maximum-Parsimony methods [Fig-2]. The NJ and MP approaches produced trees with similar topologies. The generated phylogenetic trees indicated that the members were constituted by two well differentiated clades having three well resolved groups. The three groups were formed of species of Meretricinae, Venerinae and Tapitinae.

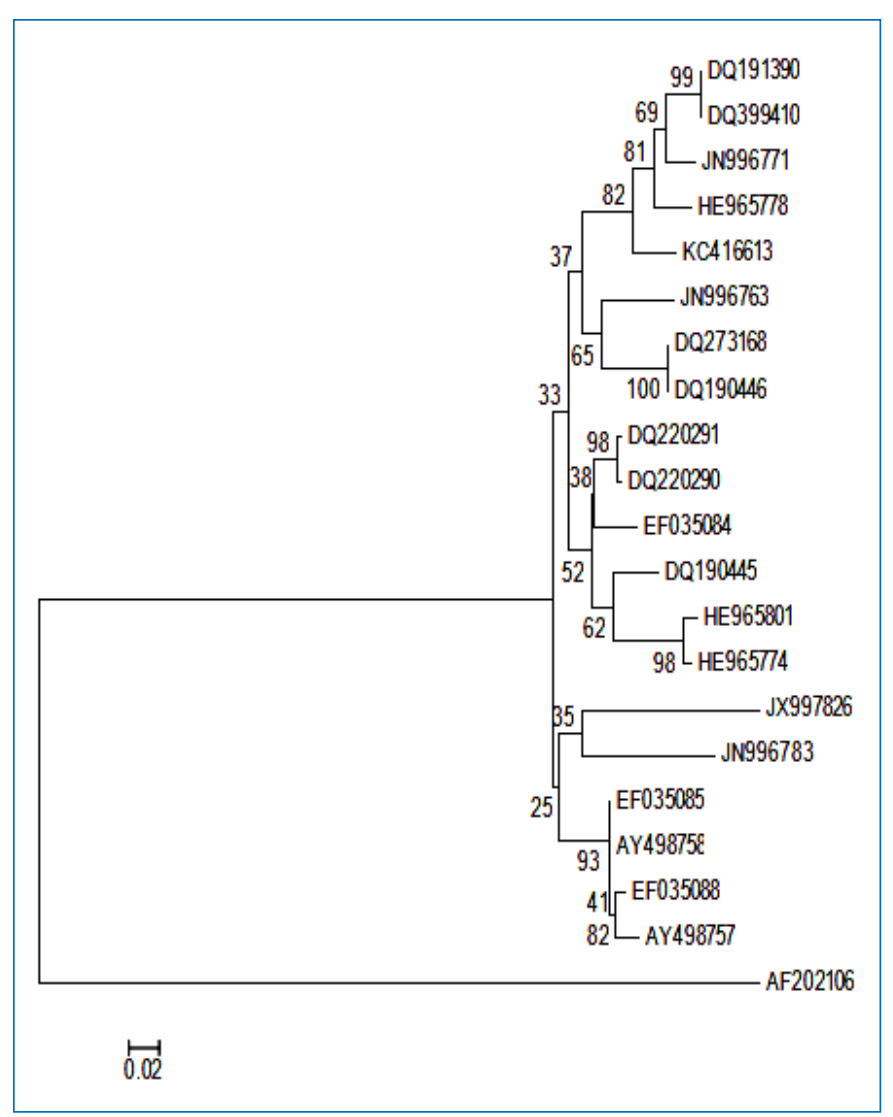

Fig. 1- Phylogenetic tree of 21 taxa inferred using Neighbor-Joining method 


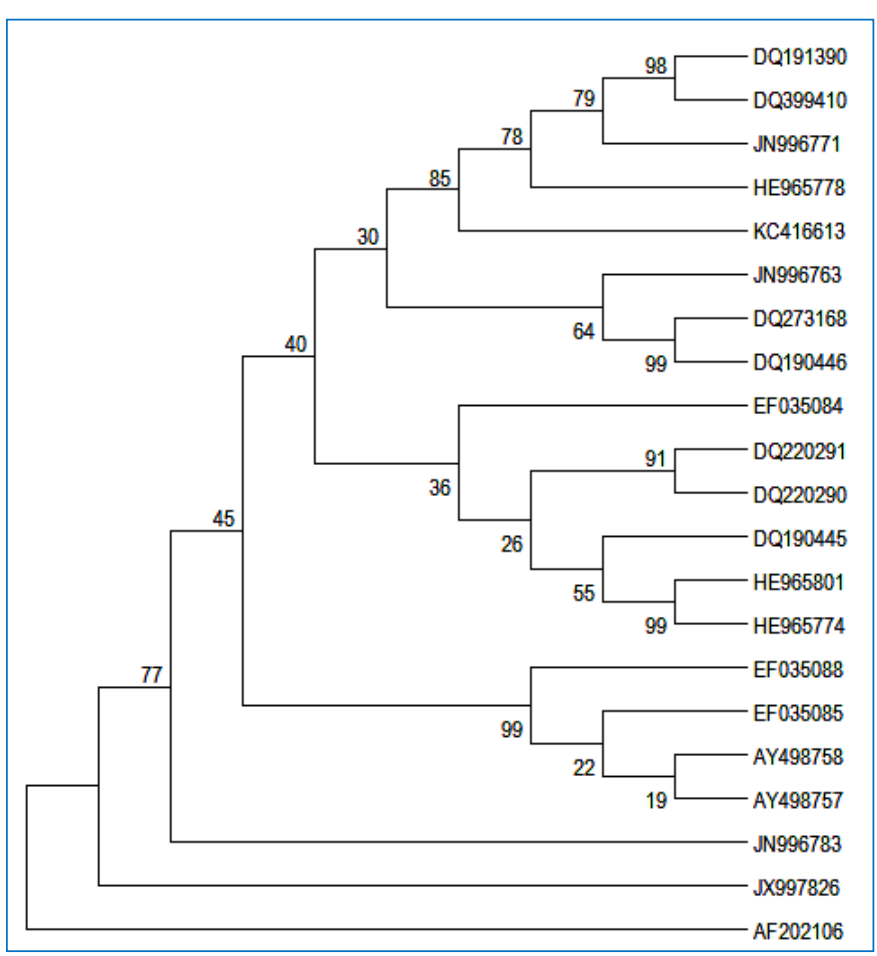

Fig. 2- Phylogenetic tree of 21 taxa inferred using MaximumParsimony method

\section{Discussion}

ITS region is highly variable, it can be utilised for phylogenetic analysis of closely related species and population [27, 28]. The present study throws light on the information about the Internal Transcribed Spacer (ITS) sequence of the nuclear ribosomal DNA of two Venerid clams Paphia malabarica and Meretrix casta. The characteristics and variations in their sequences were demonstrated through PCR amplification and sequencing.

The lengths of ITS sequence were similar to that obtained by earlier researchers for Veneridae [6] and longer than Pectinidae scallop [12]. The length of ITS1 and ITS2 in ITS sequence varies depending on the species. Many researchers obtained ITS sequences in which the length of ITS2 were twice or more than that of ITS1 $[9,11,29]$. The length of ITS1 similar to ITS2 or larger than ITS2 was reported earlier $[16,30]$. In the present study also the ITS1 regions of the two clam species were longer than the ITS2 region.

The GC content of ITS1 (58.99\% to $64.68 \%)$ and ITS2 (63\% to $72.06 \%$ ) showed a little variation in both the clam species, which is in collaboration with the results obtained earlier [12]. The amount of GC content in Meretrix casta (64.68\% in ITS1 and $72.06 \%$ in ITS2) was higher when compared to the GC content in other Veneridae clams reported earlier $[11,16]$ and other bivalves $[11,29]$. The difference of GC content between ITS1 and ITS2 was less than 8\%. Balance in GC content between the two spacers is a prominent character that occurs frequently in Veneridae species. This fact clearly confirms the co-evolution between the two spacers at the level of base compositions [31].

The ITS1 and ITS2 regions in family Veneridae exhibit extensive sequence variation and length polymorphisms. In both the spacers two relatively conserved motifs were found. This indicated that these motifs might be involved in certain nucleotide acid-related functions, such as in rRNA processing [12]. The microsatellites were absent in the ITS1 region of Paphia malabarica. The ITS2 region of the two species exhibited microsatellites. These microsatellites can serve as good markers in species identification [32].

The Neighbor-Joining and Maximum-Parsimony trees displayed identical tree topology. Both trees supported the division of the family Veneridae in to two clades. Two clades generated three well resolved groups. One group consisted of species of Meretricinae showed ancestral features such as sculpture less shell surface, absence of spines and characters of superficial burrowers with shiny periostracum. The second group was constituted by species of Venerinae and the third by Tapetinae. The division of Veneridae in to these three groups were in accordance with the morphological classification of the family [33]. The phylogenetic trees produced in the present study supported the monophyly of family Veneridae. Monophyly of family Veneridae was supported earlier by several researchers [34-40].

\section{Conclusion}

The members of Chioninae and Venerinae, that were considered to be closely related for long, fall within the same clade in both trees. Even though Chamelia gallina belongs to subfamily Chioninae, it formed sister clade with Venus verrucosa of Venerinae instead of grouping with other members of its subfamily. The branches were supported by very high bootstrap values in both trees. Members of Meretricinae and Cyclininae are closely related and together they constituted one group. Another group was constituted by members of Tapetinae. Thus it can be concluded that the results of the present study is in harmony with the results of the traditional classification.

\section{Conflicts of Interest: None declared}

\section{References}

[1] Keen A.M. (1969) Mollusca, 6(2), N491-N952.

[2] Borsa P. \& Thiriot- Quievreux C. (1990) Aquaculture, 90,20927.

[3] Harte M.E. (1992) American Malacological Bulletin, 9, 199-206.

[4] Borsa P. \& Benzie J.A.H. (1993) Journal of Molluscan Studies, 59, 275-284.

[5] Passamonti M., Mantovani B. \& Scali V. (1999) Journal of the Marine Biological Association of the United Kingdom, 79, 899906.

[6] Shimamoto M. (1996) Bulletin Institute of Oceanography (Monaco) Special Issue, 14(4), 263-270.

[7] Canapa A., Schiaparelli S., Marota I. \& Barucca M. (2003) Marine Biology, 142, 1125-1130.

[8] Chen J., Li Q., Kong L. \& Zheng X. (2011) Zoologica Scripta, 40 (3), 260-271.

[9] Yu E.T., Juinio-Meñez M.A. \& Monje V.D. (2000) Marine Biotechnology, 2, 511-516.

[10]Yu Z.N., Kong X.Y., Zhuang Z.M., Liu Y.S. \& Song L.S. (2001) Journal of Fishery Science China, 8(1), 6-9.

[11]Fernandez A., Garcia T., Asensio L, Rodriguez M.A., Gonzalez I., Hernandez P.E. \& Martin R. (2001) Journal of Food Science, $66,657-661$.

[12]Insua A., Lopez-Pinon M.J. \& Mendez J. (2003) Genome, 46, 595-604. 
[13]Vidigal T.H.D.A., Spatz L., Kissinger J.C., Redondo R.A.F., Pires E.C.R., Simpson A.J.G. \& Carvalho O.S. (2004) Mem. Inst. Oswaldo Cruz, Rio de Janeiro, 99(2), 153-158.

[14]Lee T. \& Ó Foighil D. (2005) Evolution, 59, 2139-2358.

[15]He M.X., Huang L.M., Shi J.H. \& Jiang Y.P. (2005) Marine Biotechnology, 7(1), 40-45.

[16]Cheng H.L., Meng X.P., Ji H.J., Dong Z.G. \& Chen S.Y. (2006) Journal of Shellfish Research, 25, 833-839.

[17]Wood A.R., Apte S., MacAvoy E.S. \& Gardner J.P.A. (2007) Molecular Phylogenetics and Evolution, 44,685-698.

[18]Won H. \& Renner S.S. (2005) Molecular Phylogenetics and Evolution, 36, 581-597.

[19]Jansen G., Devaere S., Weekers P.H.H. \& Adriaens D. (2006) Molecular Phylogenetics and Evolution, 38, 65-78.

[20]Winnepenninckx B., Backeljau T. \& De Wachter R. (1993) Trends in Genetics, 9, 407.

[21]Altschul S.F., Gish W., Miller W., Myers E.W. \& Lipman D.J. (1990) Journal of Molecular Biology, 215, 403-410.

[22]Thompson J.D., Gibson T.J., Plewniak F., Jeanmougin F. \& Higgins D.G. (1997) Nucleic Acids Research, 24, 4876-4882.

[23] Gouy M., Guindon S. \& Gascuel O. (2010) Molecular Biology and Evolution, 27(2), 221-224.

[24]Tamura K., Peterson D., Peterson N., Stecher G., Nei M. \& Kumar S. (2011) Molecular Biology and Evolution, 28, 27312739.

[25]Nei M. \& Kumar S. (2000) Molecular Evolution and Phylogenetics, Oxford University Press, New York.

[26]Felsenstein J. (1985) Systematic Zoology, 34, 152-161.

[27]Hillis D.M. \& Dixon M.T. (1991) Quarterly Review of Biology, 66, 410-453.

[28]Navajas M., Lagnel J., Gutterrez J. \& Boursot P. (1998) Heredity, 80, 742-752.

[29]Dahlgren T.G., Weinberg J.R. \& Halanych K.M. (2002) Marine Biology, 137, 487-495.

[30]Coleman A.W., Vacquier V.D. (2002) Journal of Molecular Evolution, 54, 246-257.

[31]López-piñón M.J., Insua A. \& Méndez J. (2002) Marine Biotechnology, 4, 495-502.

[32]Ashokan K.V., Pillai M.M., Angadi S.M. \& Mundaganur D.S. (2009) The Internet Journal of Genomics and Proteomics, 5(1), 1-19.

[33]Shimamoto M. (1986) Science Reports of the Tohoku University, Series 2: Geology = Tohoku Daigaku Rika Hokoku, Dai 2: Shu Chishitsugaku, 56(1), 1-39.

[34]Campbell D.C. (2000) Geological Society of London Special Publication, 77, 31-46.

[35]Canapa A., Marota I., Rollo F. \& Olmo E. (1996) Journal of Molecular Evolution, 43, 517-522.

[36]Canapa A., Marota I., Rollo F. \& Olmo E. (1999) Journal of Molecular Evolution, 48, 463-468.

[37]Giribet G. \& Wheeler W. (2002) Invertebrate Biology, 121, 271324.

[38]Matsumoto M. (2003) Molecular Phylogenetics and Evolution,

$$
\text { 27, 429-440. }
$$

[39]Steiner G. \& Hammer S. (2000) The Geological Society of London, London, 11-29.

[40]Williams S.T., Taylor J.D. \& Glover E.A. (2004) Journal of MolIuscan Studies, 70, 187-202. 